\title{
EL DETERIORO DEL MERCADO HIPOTECARIO Y SU RECONSTRUCCIÓN DESDE EL NUEVO MODELO EUROPEO
}

AUTORA: Esther Muñiz Espada

Edición: Aranzadi, 2016

ISBN: 978-84-9090-105-2

Colección: Aranzadi

La obra objeto de la presente recensión tiene como punto de partida la referencia a las numerosas leyes aprobadas y publicadas en España a raíz de la crisis económica sufrida sobre todo a partir del año 2009, con el fin de tratar de sofocar o paliar los efectos y las consecuencias negativas sobre el mercado hipotecario. Pese a que dicha política legislativa y las normas emanadas en los últimos tiempos bajo su perspectiva no han evitado los problemas que trataban de solucionar o bien sólo en parte han podido aportar soluciones eficaces, en todo caso no se reiteran en este libro las críticas que ya ha apuntado la doctrina, sino que añadiendo nuevas aportaciones a dicha normativa, se efectúa sirve un completo análisis para verificar la transposición de la Directiva 2014/17/UE sobre el crédito hipotecario, a fin de guiar y orientar al legislador hacia una posible recuperación del sector. Para ello se van a analizando de manera exhaustiva las propuestas y directrices de la mencionada Directiva.

La Directiva consta de 50 artículos y dos Anexos, éstos últimos sobre cálculo de la tasa anual equivalente y sobre la Ficha Europea de Información Normalizada. Se centra el interés fundamentalmente en los aspectos precontractuales, como el derecho a la información, las pautas de comportamiento y prácticas de los prestamistas así como las normas de comercialización o normas de conducta en la concesión de créditos al consumidor, la información publicitaria, el asesoramiento, la evaluación de la solvencia, el acceso a bases de datos, la tasa anual equivalente y el derecho de reembolso anticipado; de igual forma, se incide sobre las condiciones aplicables a los prestamistas y a los intermediarios de crédito, los requisitos prudenciales y de supervisión; y también a las medidas para evitar procedimientos de ejecución de los préstamos hipotecarios 
para la adquisición de vivienda. El objetivo a lograr es la consecución de una actividad del mercado de crédito hipotecario responsable en todo el territorio de la Unión Europea para la protección del consumidor.

En ese sentido, se estudian los actuales problemas suscitados en la fase de ejecución hipotecaria, debido a la inclusión de cláusulas contractuales cuya redacción permite a las entidades acreedoras bancarias frente a la parte prestataria-consumidor, llevar a cabo un ejercicio abusivo de los derechos conferidos. Y tal es el grado de «abusividad» de tales cláusulas por su sola redacción en la práctica generalidad de los casos, sobre todo en referencia a las cláusulas de vencimiento anticipado que facultan a la acreedoraprestamista para aplicar dicho efecto del vencimiento anticipado, con tan sólo el impago de una cuota de amortización (incluso añadiéndose muchas veces la expresión "total o parcial", o tan sólo de "sus intereses"). Por tal motivo, las cláusulas de vencimiento anticipado que contemplan la citada redacción, particularmente en los préstamos hipotecarios concertados por consumidores, ciertamente que no guardan sencillo acomodo a las exigencias mínimas de tutela y protección del consumidor, determinadas por el Derecho comunitario en la materia, pues a decir del TJUE en su superior interpretación del mismo, solo se adecuarían a tales exigencias del Derecho comunitario, aquéllas cláusulas de vencimiento anticipado "en los contratos de larga duración, por incumplimientos del deudor en un período limitado" -que en su redacción, se entiende- cumplieran con las mínimas exigencias que al respecto se enumeraron en la Sentencia del TJUE de 14 de marzo de 2013.

Retomando el objeto de la Directiva 2014/17/UE, éste consiste en establecer un marco común aplicable a la contratación de créditos al consumo garantizados mediante hipoteca o garantía similar, en relación con bienes inmuebles de uso residencial. En particular, incluye la obligación de evaluar la solvencia previa a la concesión del crédito, así como los requisitos en materia prudencial y de supervisión en relación también a los intermediarios de crédito, representantes designados y entidades no crediticias, permitiendo al Estado miembro la adopción de medidas tendentes a garantizar la protección del consumidor.

En definitiva, la Directiva analizada en esta obra contiene tan sólo una parte de las 
directrices a tomar en consideración, pues, por encima de ella, los acontecimientos y la realidad social exigen un replanteamiento más amplio para construir un sistema verdaderamente garantista, recuperando esa seguridad jurídica perdida, como exigencia de calidad del sistema jurídico. En la obra se analiza asimismo el ámbito de aplicación de la mencionada Directiva y sus limitaciones para proponer un planteamiento más amplio de cara a su transposición. El contenido de la norma europea no ofrece una excesiva originalidad, sin dejar de tener en cuenta algunos aspectos cuestionables así como ciertos contenidos un tanto reiterativos respecto de lo que ya habían establecido Directivas anteriores. De otro lado, se omiten detalles que deberían estar presentes en relación al incentivo de la renegociación de los préstamos hipotecarios, ya que si se apuesta preferentemente por esta salida, no obstante faltan medidas que aporten mayor flexibilidad al crédito hipotecario, como reconoce la propia autora en esta obra, la cual constituye una continuación y un paso más en relación con otros estudios y trabajos previos de gran valía e interés sobre el derecho hipotecario y el mercado hipotecario.

En conjunto la obra representa un estudio muy completo y de sumo interés no sólo sobre la mencionada Directiva y su transposición, sino para una reconstrucción más coherente y eficiente del mercado hipotecario en España, apoyado con el análisis y cita de la jurisprudencia más actual y de una completa bibliografía española y europea, todo lo cual convierten este libro en una obra de obligada referencia y consulta por los estudiosos y especialistas en la materia.

Dra. María José Zapater Espí

Universidad Politécnica de Valencia 